\title{
WHY DO INTERSTATE CONSUMPTION PATTERNS DIFFER?
}

\author{
Robert Kirk*
}

\begin{abstract}
The credibility that can be attached to information produced by regional analysts (i.e., export base and input-output multipliers), depends, in part, on the reasonableness of underlying assumptions. One of the assumptions is the uniformity of consumption patterns. Are consumption patterns uniform? The degree of spatial variation in consumption patterns in 1982 and 1987 at the state level is measured. An OLS regression model is specified to identify determinants of interstate variation in consumption. The empirical results indicate that in addition to variation in disposable income per capita, the age distribution of the population and tax effort are important determinants. Implications for state and local tax policy and economic development strategies are considered.
\end{abstract}

\section{INTRODUCTION}

This topic is relevant to regional analysts because we frequently assume consumption patterns to be uniform across spatial units (states and metropolitan areas). For example, Conway $(1990,144-45)$ assumes in describing the Washington Projection and Simulation Model that Washington's household consumption patterns are fundamentally the same on a per capita basis as the United States and, therefore, uses consumption patterns from the gross national product accounts. In the computation of location quotients, uniformity is assumed. The location quotient is used in input-output analysis as one nonsurvey method to obtain regional supply proportions, according to Miller and Blair (1985, 295-302).

Regional analysts are uncomfortable with the assumption of uniformity. For example, in a comparison of regional multipliers generated by the Washington Input-Output Model and the U.S. Department of Commerce Regional Input-Output Modeling System, Bourque $(1990,96)$ says, ". . . There is virtual unanimity among regional economists concerning the desirability of incorporating more regionally-specific information within computer-generated models." Brucker, Hastings, and Latham $(1990,122-24)$, in an assessment of five regional input-output models, indicate the importance of regionally-specific information by using as one basis for assessment: Does the model allow for user-supplied regionallyspecific consumption data?

*Professor of Economics, Indiana University-Purdue University at Indianapolis 
What problem arises if nonuniformity exists when uniformity is assumed? If a state or metropolitan area's consumption pattern is higher than the pattern of the unit used as a norm, a technique such as the location quotient will overstate the number of employees engaged in export activity. If a time-series of export employment is used to estimate regression coefficients which, in turn, are used to forecast total employment, the results will be biased upward.

What is the usefulness of identifying determinants of differences in consumption patterns? The information can assist the regional analyst in deciding when to invest additional resources to obtain regionally-specific data or to use the more readily available national data.

The title of this paper suggests that interstate consumption patterns differ. In section II, two measures of variation in consumption patterns by state for census years 1987 and 1982 are presented. ${ }^{1}$ In section III, an OLS model is specified to identify determinants of interstate differentials in consumption. In section IV, the empirical results are presented.

\section{INTERSTATE VARIATIONS IN CONSUMPTION}

Consumption at the state level is measured by retail sales as reported in the 1987 Census of Retail Trade (U.S. Bureau of the Census 1989). The retail sales covered are oriented toward durables and nondurables, with services less wellrepresented. Retail sales in a given state include primarily sales based on expenditures by residents of the state. Some retail sales transactions are generated by commuters from contiguous states. States like Florida derive significant expenditures from out-of-state tourists.

Consumption is measured by expenditures, which is the product of price and quantity. Part of the difference in expenditures for a specific category is due to price differences between states. The expenditure data were adjusted by a statespecific price index because the focus of this study is on differences arising from nonprice factors. $^{2}$

One measure of interstate variation in consumption is the percentage of the highest and lowest-valued states compared to the median. Table 1 presents this statistic by retail sales categories in 1982 and 1987.

If uniformity existed, such a wide range would not exist. Another measure of variation is the coefficient of variation, which is the standard deviation divided by the mean. Table 2 presents the coefficient of variation in percentage form.

If uniformity existed, the coefficients would be zero. Because they are not, the uniformity assumption is suspect. The coefficients are larger in 1987 than in 1982 in all but one case. Nineteen eighty-two was a recession year, while 1987 
TABLE 1

Extreme Values as a Percentage of the Median Value for Expenditures per Capita by State, by Sales Category, 1982 and 1987 (state in parentheses)

\begin{tabular}{|c|c|c|c|c|}
\hline \multirow[b]{2}{*}{ Category } & \multicolumn{2}{|c|}{1982} & \multicolumn{2}{|c|}{1987} \\
\hline & Highest & Lowest & Highest & Lowest \\
\hline Building materials & 156 (WY) & 60 (NY) & 232 (NH) & 73 (LA) \\
\hline New/used auto dealers & 156 (ND) & 66 (NY) & 165 (NH) & 71 (MS) \\
\hline Women's clothing & 163 (NJ) & 53 (ID) & 205 (NJ) & 48 (ID) \\
\hline Furniture & 141 (FL) & 53 (ND) & $165(\mathrm{NH})$ & 31 (ND) \\
\hline Food away from home & $133(\mathrm{NV})$ & 61 (MS) & 134 (FL) & 62 (MS) \\
\hline
\end{tabular}

Source: Census of Retail Trade, 1982 and 1987.

TABLE 2

Coefficient of Variation for Expenditures per Capita by State, by Sales Category, 1982 and 1987

\begin{tabular}{lll}
\hline \hline Category & 1982 & 1987 \\
\hline Building materials and supplies & 21.7 & 29.4 \\
New and used autos at car dealers & 16.7 & 18.7 \\
Women's clothing & 26.1 & 32.7 \\
Furniture & 18.4 & 25.7 \\
Food away from home & 16.4 & 15.2 \\
\hline
\end{tabular}

Source: Census of Retail Trade, 1982 and 1987.

was one of national expansion. In the empirical testing of the model, two crosssectional analyses are made-one for 1982 and one for 1987. These selected categories in the aggregate equaled 33 percent of total expenditures in 1982 and 38 percent in 1987 as reported in the Census of Retail Trade.

\section{MODEL SPECIFICATION}

The types of expenditures reported in the Census range from eating out at restaurants to buying autos and furniture. While many households eat out several times a year, they make durable goods expenditures for autos and furniture less frequently. Because time-series Census data for expenditures were unavailable, the stock-adjustment dimension of durable goods expenditures could not be modeled. 


\section{Disposable Income}

Consumption expenditures are assumed to be a function of disposable income as reported by the U.S. Bureau of Economic Analysis (1989). Because the unit of observation is the state, the data consist of 48 "representative consumers." These consumers are defined by dividing total state expenditures by state population. Thus, the concept of a "consumption pattern" refers to the average consumer in each state. A direct relationship is predicted between the dependent variable, consumption expenditures per capita, and the independent variable, disposable income per capita.

\section{Consumer Confidence}

Not only is the level of disposable income important in determining consumption, but expectations about income also affect current consumption. If people are worried about losing their jobs, consumption may be postponed. The basis for forming an expectation is the recent past. Durable goods employment tends to be more cyclical than other sectors. Therefore, consumer expectations are measured by the percentage change in the state's durable goods employment over the previous year (U.S. Bureau of Labor Statistics 1983 and 1988). A direct relationship is predicted between consumption expenditures per capita and the percent change in durable goods employment over the previous year. If change is negative, then consumption expenditures per capita will be lower.

\section{Age Distribution}

Many of the baby boomers (persons born between 1946-64) passed through the "starter home" stage of life during the 1980s, acquiring the first home necessitates expenditures for home-related goods such as furniture and building supplies. Also, in many of the baby boom households, both spouses were employed, resulting in increased demands on their time. Many households adjusted to this situation by substituting market-provided goods and services for home production, i.e., home food preparation. The baby-boomer influence is measured by the proportion of the population aged 18-35 (U.S. Bureau of the Census 1989). ${ }^{3}$ States with high proportions of this age group included Colorado, Wyoming, Vermont, South Carolina, and California, while states with low proportions were Florida, Arkansas, New Jersey, Pennsylvania, and New York. A direct relation- 
ship is predicted between consumption expenditures per capita and the 18-35 proportion of the population.

\section{State and Local Taxation}

Personal income is disposable income plus taxes. Disposable income has already been included in the model. To identify the effect of taxes on consumption, a measure of "tax climate" is used. The Advisory Commission on Intergovernmental Relations (ACIR 1983 and 1989) has been measuring state fiscal capacity and effort for several years. The Commission's measures are not computed for 1987, but are available for 1986 and 1981. The state and local tax effort in 1986 and 1981 is assumed to form a context for consumption in 1987 and 1982, respectively.

The ACIR computes both fiscal capacity and fiscal effort indices for each state. ${ }^{4}$ The effort index measures the state's actual collections compared with those collections it could gain with a national average system. For example, in 1986, Minnesota's fiscal effort index was 113, which means that its state and local governments placed a burden 13 percent higher than average on its tax bases. On the other hand, Florida's effort index was 84 percent, or 16 percent below the national average. The range in 1986 was from New York (152) to New Hampshire (62). An inverse relationship is predicted between consumption expenditures per capita and taxation as measured by the fiscal effort index.

\section{Climate}

Climate variation may affect interstate consumption patterns. Temperaturesensitive expenditures could include clothing, for example. Even within a state, climates may differ. The climate for California coastal urban areas such as San Francisco differs from interior urban areas only a short distance away, such as Sacramento. Climate has several measurable dimensions such as temperature range, precipitation, and humidity. No index exists that combines them into one measure. In this study, temperature is the focus and is measured by cooling degree days, using 65 degrees as the base (U.S. Bureau of the Census, 1985). ${ }^{5}$ When the average is above 65 , we have cooling degree days. If the number of cooling degree days is low, then the state's climate would be characterized as having cold winters and cool summers. For example, the lowest number of cooling degree days is found in Maine, while the highest number is in Arizona. One problem with this measure is that it is based on weather station-specific data rather than on a 
state average. For example, the measure used for Oregon's cooling degree days is based on the weather station in Portland. The number of cooling degree days is relatively low, reflecting the temperate climate of Portland. Where more than one station exists in a state, an average is used. Since a priori the relationship between specific kinds of consumption expenditures and climate is not clear, the data will be used to reveal the relationship.

\section{Propensity to Save}

Consumption expenditures per capita may vary across states due to differences in the consumer's saving propensity. Disposable income is consumption plus saving. Because a direct measure of saving by state, such as the proportion of personal income that is saved, does not exist, a proxy must be used.

Consumers make intertemporal allocations of income between present consumption and future consumption. This allocation is based on the consumer's marginal rate of time preference between present and future consumption and the chances to convert present consumption into more future consumption, as measured by the market interest rate. Once the allocation is determined, another decision must be made concerning the form of saving. Alternative forms include different kinds of financial and real assets. Sources of income from these assets, as measured in the National Income Accounts, include dividends, interest, and rental income. These data are available at the state level (U.S. Bureau of Economic Analysis 1989). The measure used is the proportion of personal income derived from dividends, rent, and interest. States with the highest proportions are Montana, North Dakota, South Dakota, Iowa, and Florida; states with the lowest are Louisiana, Georgia, North Carolina, South Carolina, and Utah. An inverse relationship is predicted between consumption expenditures per capita and the dividends, rent, and interest proportion of personal income.

Six explanations of interstate variation in consumption patterns have been discussed. These explanations, measures, signs of the predicted relationships, and the mnemonic forms are summarized:

1. Disposable income, disposable income per capita, (+), INCOME

2. Consumer confidence, percent change in durable goods employment over the previous year, $(-)$, CONFID

3. Age distribution, proportion of population aged 18-35, (+), BBOOM 
4. Taxation, ACIR representative tax system index, (-), TAX

5. Climate, cooling degree days, (+) or (-), CLIM

6. Propensity to save, proportion of personal income derived from dividends, interest, and rental income, $(-)$, SAVE

\section{EMPIRICAL TESTING}

The OLS cross section model is run on data for 1982 and 1987 for each of five expenditure categories. The results are presented in Table 3.

The disposable income (INCOME) coefficient was significant, with the predicted positive sign in all categories except in 1982, when the sign for autos was positive but not significant, and the sign for building materials was negative and significant. The recessionary period of 1981-82 apparently had the expected postponement effect on consumer durables such as autos, and the depressed conditions in housing discouraged complementary expenditures such as building materials. The size of the coefficients for women's clothing and eating out was the same in both years. For furniture, the coefficient was smaller in 1982. When the parameter estimates were standardized, the income variable was, not surprisingly, the most important contributor to variation. Therefore, the more a state's disposable income per capita deviates from the U.S. average, the more the assumption of uniformity becomes suspect.

The purpose of the confidence variable (CONFID) was to differentiate between the level of income and stability within the level. In 1987, only women's clothing had the predicted negative sign, suggesting that expenditures were sensitive to instability. In 1982, the sign of eating out was opposite the predicted sign. The previous year, 1981, was a recessionary year, too, so a negative percent change in durable goods employment meant a further weakening of the state's economy from an already recessionary level.

The age distribution (BВOOM) coefficient was significant, with the predicted positive sign in the 1982 model for building supplies, autos/trucks, furniture, and eating out, and in 1987 for eating out. A major contributor to employment growth during the 1980 s was that there is new restaurants, primarily in metropolitan areas. This analysis indicates a demographic dimension to this growth. With the aging of the baby boomers, restaurant operators may come under increasing pressure unless they respond to the changing market. The somewhat surprising negative sign in 1987 and 1982 for women's clothing indicates 
TABLE 3

Selected Expenditure Categories Per Capita, Coefficients and t-Statistics, 1987 and 1982

\begin{tabular}{|c|c|c|c|c|}
\hline \multirow{2}{*}{$\begin{array}{l}\text { Independent } \\
\text { Variable }\end{array}$} & \multicolumn{2}{|c|}{1987 Model } & \multicolumn{2}{|c|}{1982 Model } \\
\hline & Coefficient & t-statistic & Coefficient & t-statistic \\
\hline \multicolumn{5}{|l|}{ INCOME } \\
\hline Bldg. materials & 0.013 & $2.27 *$ & -0.013 & $-2.97 *$ \\
\hline Autos/trucks & 0.066 & $5.31^{*}$ & 0.015 & 1.09 \\
\hline Women's clothing & 0.013 & $8.42^{*}$ & 0.014 & 6.97* \\
\hline Furniture & 0.031 & $7.77 *$ & 0.019 & $5.38^{*}$ \\
\hline Food away from home & 0.027 & $5.55^{*}$ & 0.028 & $4.79 *$ \\
\hline \multicolumn{5}{|l|}{ CONFID } \\
\hline Bldg. materials & 3.04 & 0.88 & 1.03 & 1.02 \\
\hline Autos/trucks & 6.72 & 0.88 & -1.79 & -0.54 \\
\hline Women's clothing & -1.90 & $-2.00^{*}$ & 0.076 & 0.17 \\
\hline Furniture & 2.40 & 0.98 & 0.247 & 0.30 \\
\hline Food away from home & 0.69 & 0.23 & 2.55 & $1.85 * *$ \\
\hline \multicolumn{5}{|l|}{ BBOOM } \\
\hline Bldg. materials & -518.4 & -0.63 & $1,827.1$ & $4.66^{*}$ \\
\hline Autos/trucks & $-1,115.7$ & -0.62 & $4,548.6$ & $3.57^{*}$ \\
\hline Women's clothing & -417.9 & $-1.85 * *$ & -301.3 & $-1.69 * *$ \\
\hline Furniture & 321.5 & 0.55 & 626.9 & $1.94^{* *}$ \\
\hline Food away from home & $2,356.4$ & $3.36^{*}$ & $2,271.0$ & $4.26^{*}$ \\
\hline \multicolumn{5}{|l|}{ TAX } \\
\hline Bldg. material & -2.19 & $-3.24^{*}$ & -0.128 & -0.40 \\
\hline Autos/trucks & -6.22 & $-4.18^{*}$ & -1.67 & -1.60 \\
\hline Women's clothing & 0.122 & 0.65 & -0.02 & -0.17 \\
\hline Furniture & -0.558 & -1.17 & -0.089 & -0.34 \\
\hline Food away from home & -1.222 & $-2.11^{*}$ & -0.247 & -0.57 \\
\hline \multicolumn{5}{|l|}{ CLIM } \\
\hline Bldg. material & -0.03 & $-1.99 * *$ & -0.003 & -0.43 \\
\hline Autos/trucks & 0.004 & 0.14 & 0.039 & $1.97 * *$ \\
\hline Women's clothing & 0.008 & $2.16^{*}$ & 0.004 & 1.41 \\
\hline Furniture & 0.020 & $2.07^{*}$ & 0.021 & 4.24* \\
\hline Food away from home & 0.018 & 1.48 & 0.015 & $1.79 * *$ \\
\hline \multicolumn{5}{|l|}{ SAVE } \\
\hline Bldg. material & -180.0 & -0.62 & 440.0 & $3.86^{*}$ \\
\hline Autos/trucks & 119.0 & 0.18 & $1,115.2$ & $3.01 *$ \\
\hline Women's clothing & -102.6 & -1.27 & -28.4 & -0.55 \\
\hline Furniture & -334.9 & -1.66 & -7.0 & -0.08 \\
\hline Food away from home & 308.5 & 1.23 & 304.0 & $1.96^{* *}$ \\
\hline \multicolumn{5}{|l|}{ ADJ. $\mathbf{R}^{2}$} \\
\hline Bldg. material & \multicolumn{2}{|c|}{.26} & \multicolumn{2}{|c|}{.34} \\
\hline Autos/trucks & \multicolumn{2}{|c|}{.51} & \multicolumn{2}{|c|}{.27} \\
\hline Women's clothing & \multirow{2}{*}{\multicolumn{2}{|c|}{.69}} & \multicolumn{2}{|c|}{.53} \\
\hline Furniture & \multirow{2}{*}{\multicolumn{2}{|c|}{$\begin{array}{l}.57 \\
.51\end{array}$}} & \multirow{2}{*}{\multicolumn{2}{|c|}{$\begin{array}{l}.47 \\
.58\end{array}$}} \\
\hline Food away from home & & & & \\
\hline
\end{tabular}

*statistically significant at the 5 percent level, $n=48$

**significant at the 10 percent level 
that it is the disposable income variable, not the demographic one, which is critical in explaining variation in women's clothing expenditures.

In 1987, the tax (TAX) variable was an important one in explaining variation for building supplies and autos/trucks and had the predicted sign-as tax effort increased, or expenditures decreased. The standard deviation and range of the tax variable was larger in 1987 than in 1982. The changing federalism of the 1980s and constraints imposed by the federal deficit resulted in increased pressures on state and local governments to decide what to provide and how to tax in order to provide it. Incumbents are having to explain to voters why they had to cut programs, to contract out, and/or raise taxes in the face of declining federal grants and the elimination of federal revenue sharing. This analysis indicates that higher tax rates had consequences for certain expenditures.

The climate (CLIM) coefficient, when significant, had a positive sign, which means that larger per capita expenditures were associated with warmer climates. Furniture was positive in both years, and the size of the coefficient the same. Other positive coefficients were for women's clothing in 1987, and autos/trucks and eating out in 1982. In 1987, the sign was negative for building supplies, meaning that colder climates were associated with larger expenditures. Residual analysis indicated that New Hampshire and Vermont were outliers (actual greater than predicted) in 1987 reflecting the strong housing demand in New England.

Finally, what does the propensity to save (SAVE) coefficient indicate? The predicted sign is negative. In 1987, there were no significant coefficients. In 1982 , building materials, autos/trucks, and eating out were significant, but with a positive sign. An examination of the data by state indicates that the states with the highest proportions of income in dividends, rent, and interest were Florida, Iowa, South Dakota, North Dakota, and Montana. These high DIV states were ones with significant proportions of elderly population, with Florida being the obvious example. The disposable income in these states would be less dependent on the wage and salary income, which is the disposable income component that would be most directly impacted by the 1982 recession. Thus, the positive sign is plausible. To test the regression model for multicollinearity, the diagnostic test used looked for large (greater than .5) variance-decomposition proportions. Based on this test, multicollinearity was not a problem.

How sensitive are various consumption expenditures to the variables in the model? In Table 4, elasticities calculated at the mean are presented for statistically-significant coefficients in Table 3.

Elasticities equal to or greater than one were found for the following: income (INCOME) elasticities for women's clothing (1987 and 1982) and furniture (1987); and age distribution (BBOOM) elasticities for building supplies (1982), autos and trucks (1982), women's clothing (1987 and 1982), furniture (1982), and 
TABLE 4

Elasticities by Expenditure Category, 1987 and 1982

Expenditure category

1987

1982

Building materials

INCOME

.61

$-.71$

BBOOM

TAX

$-.81$

CLIM

$-.13$

SAVE

New/used autos/trucks

INCOME

BBOOM

TAX

$-.54$

CLIM .07

SAVE

Women's clothing

INCOME

CONFID

$-.01$

BBOOM

$-1.26$

$-1.22$

CLIM

Furniture

INCOME

BBOOM

CLIM

Eating out

INCOME

CONFID

BBOOM

TAX

$-.22$

CLIM 
eating out (1987 and 1982). Climate (CLIM) and consumer confidence (CONFID) elasticities were small. State and local tax effort (TAX) elasticities were rather sizable for building supplies and autos/trucks. Designers of state and local tax policy need to be aware of these tax impacts.

\section{CONCLUSIONS}

The credibility that can be attached to the export-base and input-output multipliers produced by regional analysts depends, in part, on the reasonableness of underlying assumptions. One of those assumptions, the uniformity of consumption patterns, has been examined in this paper. The degree of spatial variation for selected expenditure categories has been measured. Determinants of variation have been identified.

Variation in disposable income per capita, the age distribution of the population, and tax policy were important determinants of interstate variation. The application of the model in 1982, a recession year, indicated that the type of income, dividend, rent, and interest can be important. This paper does not measure how much more model integrity can be obtained by using regionally-specific consumption patterns. It does point to those variables that contribute to interstate differentials. If the regional analyst finds that the state being studied is characterized by values of these variables that diverge from the national values, then more research resources should be invested to obtain state-specific information for inclusion in the model. As Giarratani $(1990,223)$ advises, "One cannot be a good regional economist or regional scientist-and one cannot expect to develop a good regional input-output model-unless one knows something about regions." Only after we have become very familiar with our respective states can we offer personal warranties on the information our models generate.

Future work will take the direction of 1) extending the analysis to the metropolitan area, 2) examining other selected expenditure categories, including services, and 3) applying sensitivity analysis to measure the distortion arising from assuming national, rather than regional, consumption patterns.

\section{ENDNOTES}

1. These years are used because the economic censuses, of which retail trade is a part, are taken every five years for those years ending in "2" and "7."

2. The U.S. Bureau of Labor Statistics no longer produces cost of living data in its Family Budget series. As an alternative, the American Chamber of Com- 
merce Researchers Association (1982 and 1987) data were used. These data have limitations. Reporting is done on a voluntary basis by local chambers of commerce and, therefore, some major cities are not included. Every quarter, each city is compared with the national average of all participating cities. Most states are represented by at least one city. In states with several participating cities, a population-weighted index was used.

3. A narrower age range for first-time homebuyers, such as $23-35$, would have been preferred, but census estimates were not made for this cohort.

4. The fiscal capacity index indicates a "representative" state-local system of tax rates and bases for a particular year, using national average tax rates and typical tax bases (Advisory Commission on Intergovernmental Relations 1983 and 1989).

5. Cooling degree days are calculated by computing an average temperature for the 365 days per year and comparing it with 65 degrees. For example, if the maximum is 70 and the minimum is 52 , the average for the day is 61 , which results in four heating degree days. Heating degree days, another measure of climate, was not included because it was highly correlated with cooling degree days.

\section{REFERENCES}

Advisory Commission on Intergovemmental Relations. 1981 Tax Capacity of the Fifty States, A-93. Washington, D.C.: ACIR (September 1983) Table A.

American Chamber of Commerce Researchers Association. Inter-City Cost of Living Index. (1987 and 1982): Section 1.

Bourque, Philip J. "Regional Multipliers: WAIO vs. RIMS." International Regional Science Review 13 (1990): 87-98.

Brucker, Sharon M., Steven E. Hastings, and William R. Latham III. "The

Variation of Estimated Impacts from Five Regional Input-Output Models." International Regional Science Review 13 (1990): 119-39.

Cohen, Carol E. "State Fiscal Capacity and Effort: An Update." Intergovernmental Perspective 15 (Spring 1989): 15-20.

Conway, Richard S. "The Washington Projection and Simulation Model: A Regional Interindustry Econometric Model." International Regional Science Review 13 (1990): 141-66.

Giarratani, Frank. "Summary Comments." International Regional Science Review 13 (1990): 221-23.

Miller, Ronald E., and Peter D. Blair. Input-Output Analysis: Foundations and Extensions. Englewood Cliffs, N.J.: Prentice-Hall, 1985. 
U.S. Bureau of the Census. 1987 Census of Retail Trade. Geographic Area Series. Washington, D.C.: U.S. Government Printing Office, July 1989. "State Population and Household Estimates, with Age, Sex, and Components of Change, 1981-88." Current Population Reports Series P-25, No. 1044. Washington, D.C.: U.S. Government Printing Office, August 1989.

. Statistical Abstracts of the United States: 1985. 105th Ed. Washington, D.C.: U.S. Government Printing Office, 1984: 218.

U.S. Bureau of Economic Analysis. Local Area Personal Income, 1982-87. computer tape. (October 1989).

U.S. Bureau of Labor Statistics. Geographic Profile of Employment and Unemployment. Bulletin 2170. Washington, D.C.: U.S. Government Printing Office, Bulletin 2305. Washington, May 1983. 